\title{
触 New Disease Reports \\ First report of the rust Puccinia komarovii on Impatiens parviflora in the UK
}

K.M. Pollard*, D. Kurose, S. Varia, H.C. Evans and C.A. Ellison

CABI-UK, Bakeham Lane, Egham TW20 9TY, UK

*E-mail: k.pollard@cabi.org

Received: 18 Dec 2019. Published: 12 Jan 2020. Keywords: plant disease, rust fungus, small balsam

Impatiens parviflora, commonly known as small balsam, is an invasive plant native to the mountains of central Asia. Intentionally introduced through botanical curiosity, this plant has spread rapidly throughout Europe where it has naturalised and can form dense stands in forests and forest edges. On 4 September 2013, uredinia and telia of the rust fungus Puccinia komarovii were identified on the abaxial leaf surface of I. parviflora (Balsaminaceae) at Northchurch Common, Hertfordshire, UK (51.788326, -0.596067) (Fig. 1). Impatiens parviflora was found in an open beech woodland growing alongside Geranium sp., Glechoma hederacea, Pteridium aquilinum, Rubus fruticosa and Urtica dioica.

To confirm the identification of the rust, the ITS2-LSU region sequence was amplified with the Rust2inv (Aime, 2006) and LR6 (White et al., 1990) primers and sequenced (GenBank Accession No. LC494104). A BLAST search revealed $99 \%$ identity to $P$. komarovii collected from I. parviflora (KC460259) and I. glandulifera (KC460250). Microscopic examination confirmed spore size to be on average $34 \times 20.4 \mu \mathrm{m}$ and 18.8 $\times 17.6 \mu \mathrm{m}$ (length $\times$ width) for the teliospores and urediniospores respectively (Fig. 2), within the range reported in Tanner et al. (2015).

Distinct pathotypes of $P$. komarovii exist which are highly specific towards their hosts (Tanner et al., 2015). These pathotypes are morphologically and molecularly indistinguishable and require cross inoculation studies to differentiate them. Using the methodology outlined in Tanner et al. (2015), urediniospores removed from infected leaves were mixed with talcum powder at a ratio of approximately 1 to 50 and brushed onto the lower leaf surface of two leaves of four I. glandulifera and I. parviflora plants. Plants were lightly misted with sterile distilled water before placing in a dew chamber set at $15^{\circ} \mathrm{C}$, for 48 hours. Symptoms were first observed on I. parviflora eight days after inoculation with the development of chlorotic spots on the upper leaf surface and uredinial sporulation recorded a further eight days later. No symptoms were observed on I. glandulifera six weeks after inoculation.

Reports of $P$. komarovii on I. parviflora have been well documented; it was first recorded in Europe in Kiev, Ukraine in 1921 (Sydow, 1935). Since then the rust has spread westward throughout continental Europe and is now present in at least 21 European countries. More recently it was recorded in Belgium in 2009; this is the first report of the pathogen in the UK. Due to the location of this finding and the presence of the rust in continental Europe, it is likely that the rust is present elsewhere in UK; in 2019 we observed the rust in Egham, Surrey $(51.418154,-0.569643$ ) (Fig. 3 ), confirming its identity through inoculation studies as outlined above.

\section{References}

1. Aime MC, 2006. Toward resolving family-level relationships in rust fungi (Uredinales). Mycoscience, 47, 112-122. http://dx.doi.org/10.1007/S10267-006-0281-0

2. Piskorz R, Klimko M, 2006. The effect of Puccinia komarovii Tranzsch. infection on characters of Impatiens parviflora DC. in Galio silvatici-carpinetum (R. tx. 1937) Oberd. 1957 forest association. Acta Societatis Botanicorum Poloniae 75, 51-59. http://dx.doi.org/10.5586/asbp.2006.008

3. Sydow H, 1935. Einzug einer asiatischen Uredinee (Puccinia komarowi Tranzsch.) in Deutschland. Annales Mycologici, Berlin $\mathbf{3 3}$ 149-208.

4. Tanner RA, Ellison CA, Seier MK, Kovács GM, Kassai- Jáger E, Berecky Z, Varia S, Djeddour D, Singh MC, Csiszár A, Csontos P, Kiss L, Evans HC, 2015. Puccinia komarovii var. glanduliferae var. nov.: a fungal agent for the biological control of Himalayan balsam (Impatiens glandulifera). European Journal of Plant Pathology 141, 247-266. http://dx.doi.org/10.1007/s10658-014-0539-x

5. White TJ, Bruns T, Lee S, Taylor J, 1990. Amplification and direct sequencing of fungal ribosomal RNA genes for phylogenetics. In: Innis MA, Gelfand DH, Sninsky JJ, White TJ, eds. PCR Protocols: A Guide to Methods and Applications. San Diego, CA, USA: Academic Press, 315-322. http://dx.doi.org/10.1016/B978-0-12-372180-8.50042-1

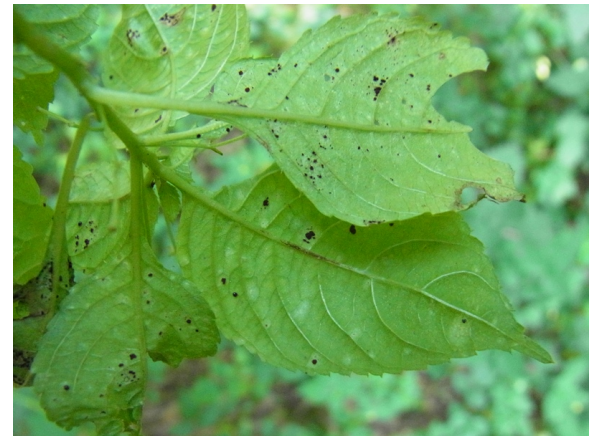

Figure 1

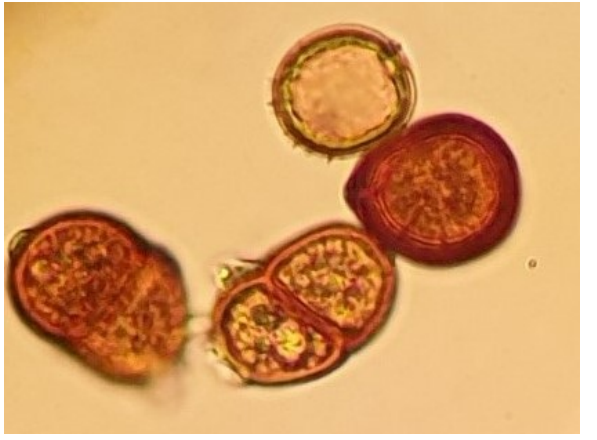

Figure 2

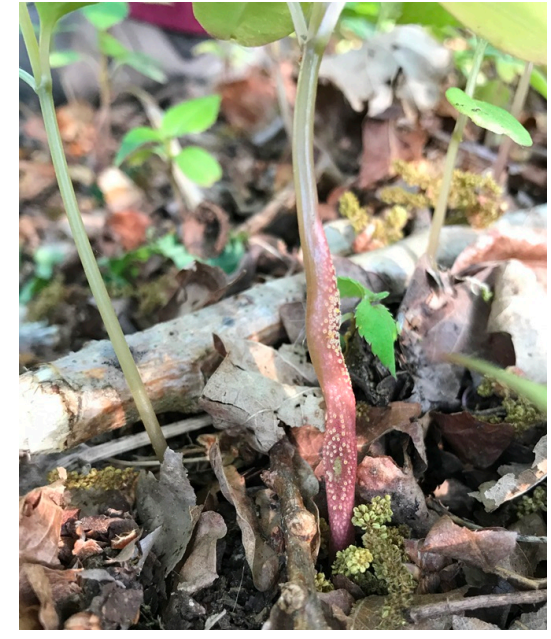

Figure 3

To cite this report: Pollard KM, Kurose D, Varia S, Evans HC, Ellison CA, 2020. First report of the rust Puccinia komarovii on Impatiens parviflora in the UK. New Disease Reports 41, 4. http://dx.doi.org/10.5197/j.2044-0588.2020.041.004 